\begin{tabular}{|c|c|c|}
\hline \multirow{2}{*}{ Márcio Caniello } & $\cdots \cdots \cdots \cdots \cdots \cdots \cdots$ & \\
\hline & 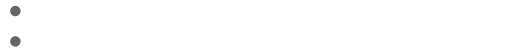 & $\begin{array}{l}\text { Raizes, } \\
\text { Ano XVIII }\end{array}$ \\
\hline \multirow{4}{*}{$\begin{array}{r}\text { Doutorando em Sociologia (UFPE), Professor da UFPB (Campus II), } \\
\text { Contato: caniello@terra.com.br. }\end{array}$} & : & $\begin{array}{l}\text { Ano } 2 \text { VIII, } \\
N^{0} 20,\end{array}$ \\
\hline & : & novembro/ \\
\hline & - & \\
\hline & : & pp. 119-131 \\
\hline
\end{tabular}

\title{
As raízes da nacionalidade no Brasil colonial
}

\author{
"O Brasil vacila entre o pessimismo mais obtuso \\ e a esperança mais frenética"
}

(Nélson Rodrigues)

\begin{abstract}
RESUMO
O objetivo deste ensaio é fazer um "balanço" da gênese da formação nacional do Brasil, com o intuito de auxiliar na superação de um dos maiores paradoxos da mentalidade brasileira: a nossa incapacidade em contrabalançar autocrítica e auto-estima quando nos avaliamos como um "povo". Neste sentido, analisamos, sob a heurística da Sociologia Histórica, dois processos essenciais da construção nacional que repercutiram na constituição do ethos brasileiro: a formação do povo articulada à defesa da soberania territorial e a configuração da cidadania. Por um lado, a bem-sucedida aliança militar entre lusos e índios, encetada para defender o território da invasão estrangeira, produziu a primeira expressão cultural genuinamente nacional, a guerra brasílica, a qual simboliza nossas maiores potencialidades como povo. Por outro lado, a configuração da "cidadania à brasileira" assentou-se sob um estatuto da desigualdade civil, base ética da exclusão social, o nosso principal "problema nacional".

Palavras-chave: construção da nação; Sociologia Histórica; Ethos
\end{abstract}

\section{ABSTRACT}

The objective of this essay is "to strike a balance" of the genesis of Brazil national formation, intending to aid the overcoming of one of the biggest paradoxes of Brazilian mentality: the incapacity of individuals to equilibrate self-criticism and self-esteem in their self-evaluation as "people". In this sense, we analyse, under the Historical Sociology heuristics, two essential processes of nation building that rebounded in the constitution of Brazilian ethos: the formation of the people articulated with the defence of the territorial sovereignty, and the configuration of citizenship. On the one hand, the successful military alliance between Portuguese and Indians, made to defend the territory from foreign invasion, produced the first genuinely national cultural expression, the guerra brasilica, that symbolise the Brazilian people most important potentialities. On the other hand, citizenship in Brazil was configured under a civil inequality statute, ethical basis of the social exclusion, the main Brazilian "national problem". Key words: nation building; Historical Sociology; ethos.

A comemoração dos 500 anos do Descobrimento do Brasil impõe um questionamento ao observador mais crítico: o que esse fato significa realmente, já que sabemos pela Arqueologia que o homem "descobriu" e ocupou o nosso atual território há, no mínimo, vinte mil anos? Além disso, que importância terá o Descobrimento, se a História registra que no momento em que a esquadra de Cabral tocou a costa sul- americana uma população de alguns milhões de índios senhoreava as terras brasileiras?

Ora, apesar de os índios serem os primeiros habitantes do território, eles eram, até a chegada dos portugueses, "invisíveis" para a consciência histórica ocidental. Eles tinham uma cultura própria em nada inferior à européia, como hoje nos ensina a Antropologia, mas estavam isolados do resto do mundo no momento em que se iniciava o grande movimento de expansão econômica que redundou no que atualmente chamamos de globalização. Mais cedo ou mais tarde, os íncolas seriam encampados por essa ordem mundial ávida por mercados e mercadorias. De uma forma ou de outra, as populações nativas seriam abordadas pelos braços e chutes do capitalismo nascente.

É importante analisar criticamente esse processo, pois sabemos que o chamado "progresso do capitalismo" produziu e ainda produz graves conseqüências, sobretudo para as populações subalternas, mas o fato é que uma situação histórica origi- 
nal foi definida a partir do momento em que Cabral desembarcou em Porto Seguro. Uma nova dinâmica social começou a se configurar no imenso, selvagem, exuberante e rico território tropical que as convenções diplomáticas internacionais reconheciam como legitimamente português. Quer dizer, a chegada dos lusos à América representa o marco zero da formação nacional brasileira, pois a partir de então iniciou-se o processo de formação do "povo

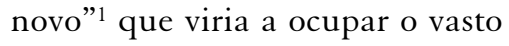
território e com isso construir uma identidade cultural e um perfil social próprios, gerados a partir da fusão dos muitos elementos que contribuíram para a formação da nossa ancestralidade.

Portanto, o que estamos comemorando neste momento são os 500 anos da nação brasileira. Mas, "comemorar" significa "rememorar" ou "trazer à memória”, o que é um ato crivado por sentimentos existenciais, pois ao refletirmos sobre o passado, nos aproximamos dos dilemas do presente. Assim, a comemoração, especialmente a festa aniversária, é um ritual através do qual celebramos a nossa existência, refletimos sobre o seu sentido e a projetamos em perspectiva. No caso das datas comemorativas nacionais isso é potencializado, porque elas simbolizam a nossa existência como um "povo" e, em virtude disso, temos a oportu- nidade de refletir criticamente sobre a história da nossa sociedade, pensando em forjar o nosso destino como nação. Talvez seja esta a grande tarefa que devamos assumir no âmbito das comemorações dos 500 anos do Descobrimento.

Esta reflexão crítica, contudo, tem que superar um dos dilemas mais recorrentes da "mentalidade brasileira": a dificuldade que temos em contrabalançar auto-estima e autocrítica em nossa avaliação sobre nós mesmos, pois, quando nos olhamos como povo, ou nos vemos como semideuses - aliás, reza o ditado, 'Deus é brasileiro' - ou como pobres-diabos - aliás, reza o chulo, 'Eta, povinho bunda'. Ou seja, quando exercemos a auto-estima, somos ingenuamente ufanistas e, quando realizamos a autocrítica, somos impiedosamente depreciativos. Aliás, recentemente, Roberto DaMatta levantou a questão da "recorrente visão negativa de nós mesmos", ao avaliar "a incapacidade de separarmos a crítica honesta da autoflagelação" que se rebate, inclusive, no "contexto das tradições de estudos notoriamente negativos da identidade nacional brasileira"2. Quer dizer, seja entre o vulgo seja entre a intelligentsia, não conseguimos colocar na balança nossos defeitos e nossas qualidades como povo, nem construir uma reflexão objetiva sobre nossas possibilidades como nação. Assim, não podemos encarar nossos problemas como fatos historicamen- te produzidos e, conseqüentemente, não conseguimos avaliar honestamente a potencialidade que temos de solucioná-los.

Para tentar superar esse dilema devemos tomar duas atitudes básicas, aproveitando o contexto festivo: por um lado, revigorar o orgulho nacional, porque um povo sem amor próprio não é dono de sua autodeterminação; por outro, avaliar sobriamente os problemas estruturais da nossa sociedade porque um povo sem autocrítica não é dono do seu destino. Portanto, há que se imprimir dois sentidos às comemorações dos 500 anos do Brasil: encará-las como um rito de afirmação da nacionalidade e como um momento precioso de reflexão existencial. Ambos necessitam, para isso, de uma única base: a consciência histórica.

Ora, a História é uma narrativa reveladora. Ela é o repositório da experiência social acumulada no tempo e, por isso, expõe características coletivas típicas, processos sociais recorrentes e elementos estruturais de uma sociedade - evidências seguras para procedimentos interpretativos e teóricos ${ }^{3}$. Assim, é olhando para a história do Brasil que poderemos fazer um "balanço" da nossa existência como povo, identificando os pontos positivos e negativos do processo de construção nacional, e, tomando consciência deles, teremos condições não apenas

\footnotetext{
$\ldots \ldots \ldots$

- ${ }^{1}$ Ribeiro, Darcy, Os brasileiros (I - Teoria do Brasil). $8^{\mathrm{a}}$ ed. Petrópolis, Vozes, 1985 [1972]: 70.

- ${ }^{2}$ DaMatta, Roberto, "Dilemas aculturativos e democracia na virada do milênio: considerações muito gerais e intuitivas sobre o caso do Brasil". Trabalho apresentado no Congresso Brasil-Portugal ano 2000, Sessão de Antropologia e Sociologia. Recife, mimeo, 1999: 2.

- ${ }^{3}$ Cf. Stinchcombe, Arthur L., Theoretical Methods in Social History. New York; London, Academic Press, 1978: 13/17.
} 
de recuperar o passado, mas de entender o presente, pois, como ensina Norbert Elias, “isto aponta para uma das tarefas que a Sociologia ainda não enfrentou - e, ao mesmo tempo, para um método que pode ajudar uma nação a conciliar-se com o seu passado"4.

Entretanto, o que é uma nação? Muita tinta já se verteu em torno desta questão abrasadora para as Ciências Sociais ${ }^{5}$, mas podemos dizer, grosso modo, que uma nação é uma "comunidade política" ${ }^{\circ}$ assentada sobre um território soberano, cujos membros pertencem a uma mesma tradição étnica e cultural e se submetem a uma mesma ordenação institucional. Isto em termos formais porque, se quisermos esquadrinhar a questão, chegaremos ao conceito de nação como uma "comunidade imaginada" , ou seja, como uma entidade congregadora de "atributos culturais mais permanentes, como memória, valor, mito e simbolismo" ". A propósito, foi partindo dessa perspectiva menos substancialista e mais subjetivista que Marcel Mauss, em artigo seminal, sentenciou: "todos os cidadãos que compõem [uma nação] participam, em suma, da Idéia que a governa" ${ }^{\text {. }}$ Aqui chegamos à própria Filosofia da História de Hegel, para quem uma nação se define, sobretudo, pelo "espírito do povo" (Volksgeist) ${ }^{10}$, já que o verdadeiro objeto da História "não são os destinos, nem as paixões, nem as energias dos povos junto aos quais se impelem os acontecimentos, senão o espírito dos acontecimentos, o que faz irromper os acontecimentos" 11 .
Quer dizer, para além de seus elementos mais comezinhos, uma nação é verdadeiramente reconhecida pelo seu ethos, "o sistema de idéias e valores que dominam a cultura e tendem a controlar o tipo de comportamento dos seus membros" 12 . Ora, valores e idéias são "representações coletivas" e, desta maneira, configuram-se como constructos sociais ${ }^{13}$; eles não são um dado da consciência individual, mas um produto da experiência histórica. Sendo assim, sua abordagem deve articular a História e a Sociologia e, como tal, terá que se reportar, por um lado, ao processo que os produziu e, por outro, à forma através da qual eles são manifes$\operatorname{tados}^{14}$.

Em relação à questão que estamos discutindo, a dinâmica sócio-

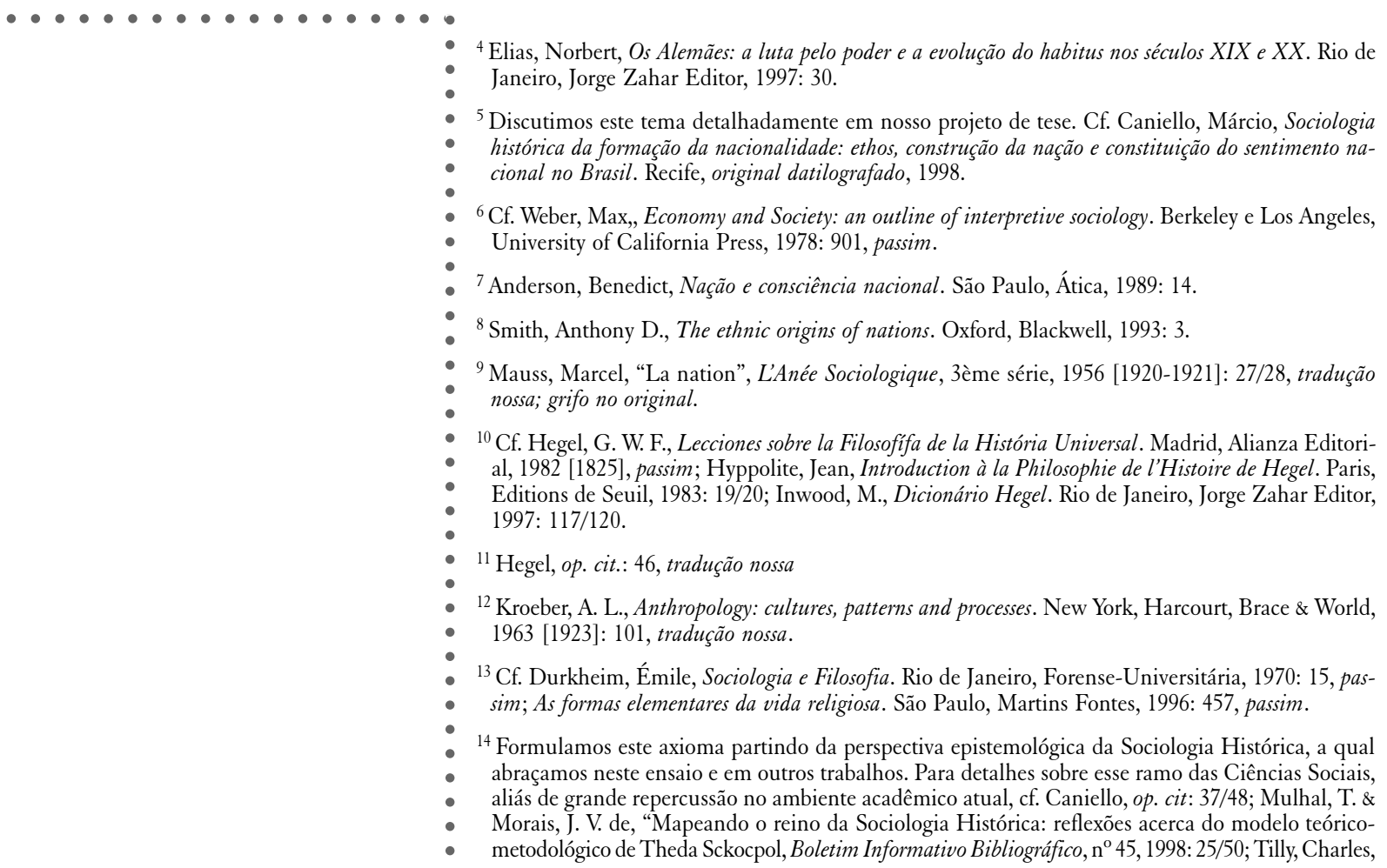

- ${ }^{4}$ Elias, Norbert, Os Alemães: a luta pelo poder e a evolução do habitus nos séculos XIX e XX. Rio de Janeiro, Jorge Zahar Editor, 1997: 30.

${ }^{5}$ Discutimos este tema detalhadamente em nosso projeto de tese. Cf. Caniello, Márcio, Sociologia histórica da formação da nacionalidade: ethos, construção da nação e constituiçãa do sentimento nacional no Brasil. Recife, original datilografado, 1998.

${ }^{6}$ Cf. Weber, Max, Economy and Society: an outline of interpretive sociology. Berkeley e Los Angeles, University of California Press, 1978: 901, passim.

${ }^{7}$ Anderson, Benedict, Nação e consciência nacional. São Paulo, Ática, 1989: 14.

${ }^{8}$ Smith, Anthony D., The ethnic origins of nations. Oxford, Blackwell, 1993: 3.

${ }^{9}$ Mauss, Marcel, “La nation”, L’Anée Sociologique, 3ème série, 1956 [1920-1921]: 27/28, tradução nossa; grifo no original.

${ }^{10}$ Cf. Hegel, G. W. F., Lecciones sobre la Filosofifa de la História Universal. Madrid, Alianza Editorial, 1982 [1825], passim; Hyppolite, Jean, Introduction à la Philosophie de l'Histoire de Hegel. Paris, Editions de Seuil, 1983: 19/20; Inwood, M., Dicionário Hegel. Rio de Janeiro, Jorge Zahar Editor, 1997: 117/120.

${ }^{11}$ Hegel, op. cit.: 46, tradução nossa

${ }^{12}$ Kroeber, A. L., Anthropology: cultures, patterns and processes. New York, Harcourt, Brace \& World, 1963 [1923]: 101, tradução nossa.

${ }^{13}$ Cf. Durkheim, Émile, Sociologia e Filosofia. Rio de Janeiro, Forense-Universitária, 1970: 15, passim; As formas elementares da vida religiosa. São Paulo, Martins Fontes, 1996: 457, passim.

${ }^{14}$ Formulamos este axioma partindo da perspectiva epistemológica da Sociologia Histórica, a qual abraçamos neste ensaio e em outros trabalhos. Para detalhes sobre esse ramo das Ciências Sociais, aliás de grande repercussão no ambiente acadêmico atual, cf. Caniello, op. cit: 37/48; Mulhal, T. \& Morais, J. V. de, "Mapeando o reino da Sociologia Histórica: reflexões acerca do modelo teóricometodológico de Theda Sckocpol, Boletim Informativo Bibliográfico, $\mathrm{n}^{\circ}$ 45, 1998: 25/50; Tilly, Charles, 
histórica que havemos de penetrar se compõe de dois processos: a formação étnica do povo brasileiro articulada à definição do território nacional e a gênese da cidadania no Brasil. O primeiro processo associa os dois fatores básicos para a construção nacional, já que o homem e sua terra formam a substância da nação. A cidadania é o seu termo, uma vez que ela é o liame mais essencial entre o agente e a estrutura, pois ela realiza eticamente a relação entre a ação do indivíduo e a norma geral, entre o discernimento pessoal e a razão coletiva, entre a idiossincrasia do sujeito e os valores da coletividade, entre a integridade do cidadão e a força do Estado.

De maneira efetiva, os dois fatores básicos se entrelaçam nas primícias da história da formação nacional brasileira sob o contexto da luta pela salvaguarda do território empreendida contra franceses e holandeses - na nossa equação, essa luta revelará, sobretudo, a positividade essencial do espírito do povo brasileiro. Cumpre ressaltar que a soberania territorial é a condição material básica para que um povo construa sua nação, pois somente um espaço de sociabilidade determinado favorece cabalmente a definição do consenso político-institucional e do perfil cultural próprios que prefiguram o "jeito de ser" desse povo, a forma pela qual ele expressa seus valores e idéias na prática social, ou seja, a própria raiz de sua identidade, visto que "a cultura exprime precisamente um estilo, um modo e um jeito de fazer as coisas.” ${ }^{15}$. Assim, a história da formação territorial é um vetor decisivo na constituição da nacionalidade, ainda mais porque, no caso do Brasil, ela envolveu eventos cruciais de grande mobilização coletiva, em que a luta pela salvaguarda do território irá revelar o seu próprio "estilo", que age como matriz e moeda neste processo. Por outro lado, no âmbito dessas lutas constituir-se-ão, ardentemente, os fatores germinais do sentimento nacional, os quais alimentam a auto-estima do povo: o amor à terra e o orgulho da raça ${ }^{16}$.

Em contrapartida, a gênese da constituição da cidadania no Brasil nos revelará ao mais pesado ponto negativo do processo de formação nacional: a configuração do estatuto da desigualdade civil. Consideramos que a cidadania é uma área onde o "jeito de ser" de um povo se expressa de uma maneira especialmente dramática, já que ela veicula, sobretudo, o que denominamos em outra ocasião de "padrão ético", a gramática do comportamento e o desiderato moral operantes em uma sociedade ${ }^{17}$. De mais a mais, a cidadania é uma área particularmente problemática, pois ela é a salvaguarda do bem-estar e o guia do bomproceder, constituindo-se num atributo conferidor de civilidade. Assim, podemos dizer que identificamos a essência de uma nação ao entendermos como nela forjou-se a cidadania e que, neste sentido, reconhecemos a "cidadania à brasileira", por um lado, como um caractere nacional, porque ela foi, no seu caldeamento original, e é, ainda hoje, vazada por uma ética pessoalizante e por uma "lógica relacional"18, e, por outro, como um problema nacional porque esteve, desde sempre, corrompida por uma desigualdade perene entre os cidadãos, raiz da torpe exclusão social que assola o povo brasileiro.

\footnotetext{
Roads from past to future. Lanham e Oxford, Rowman \& Littlefield, 1997: 17/33; Smith, Dennis, The rise of Historical Sociology. Philadelphia, Temple University Press, 1991, passim; Abrams, Philip, Historical Sociology. Ithaca, New York, Cornell University Press, 1982, passim.

${ }^{15}$ DaMatta, Roberto, O que faz o brasil, Brasil?. Rio de Janeiro, Rocco, 1986: 17.

${ }^{16}$ Não há aqui qualquer relação com o conceito biológico da raça. Quando falamos em "raça" estamos aludindo à "honra étnica, a honra específica das massas por ser acessível a todos os que pertencem à comunidade de descendência subjetivamente imaginada" (Weber, op. cit.: 391, tradução nossa).

${ }^{17}$ Caniello, Márcio, Sociabilidade e padrão ético numa cidade do interior: carnaval, política e vida cotidiana em São João Nepomuceno - MG". Dissertação de Mestrado. Rio de Janeiro, PPGAS/Museu Nacional, 1993: 9.

- ${ }^{18}$ Cf. DaMatta, Roberto, Carnavais, malandros e heróis: para uma sociologia do dilema brasileiro. Rio de Janeiro, Zahar, 1983 [1978], passim; A casa e a rua: espaço, cidadania, mulher e morte no Brasil. - Rio de Janeiro, Guanabara, 1987: 71/104.
} 
Portanto, abordaremos neste ensaio dois processos de nossa formação nacional que estão em pratos diferentes da balança: a relação do povo com a terra e a ordenação jurídica emanada da elite. Este é o exercício que nos propomos a desenvolver, restringindo-nos, em função de licenças metodológicas sobre as quais não vale a pena discutir agora, à história dos primeiros anos da vida brasileira, aquele período fortemente depreciado da história do Brasil mas durante o qual eclodiu, pensamos, as raízes da nacionalidade. Neste sentido, tomaremos como referência um autor que é uma instituição nacional, ainda que permaneça, como tantas outras altas expressões da alma brasileira, envolto num manto de esquecimento. Trata-se de frei Vicente do Salvador, um baiano da vila de Matoim, nascido Vicente Rodrigues Palha, em 1564, a quem se atribui o pioneirismo não apenas na nossa historiografia ${ }^{19}$, mas na própria literatura brasileira em prosa $^{20}$. Talvez seja o momento de recuperá-lo, tanto para revigorar nossa auto-estima, quanto para afinar nossa autocrítica, pois sua $H$ istória do Brasil ${ }^{21}$, dada à luz em 1627, é o primeiro livro escrito por um brasileiro nato e a força dessa narrativa historiográfica levou Manoel Bomfim a considerar o frade baiano como o "primeiro definidor da tradição brasileira” 22 e Francisco Iglésias a demonstrar que o seu livro revela "boa prática da historiografia de todos os tempos, por uma sensibilidade aguda de sua problemática”23.

\section{O povo e a terra da nação}

A história do Brasil no século XVI é uma história de definição territorial e étnica: a formação de um "povo novo" e a disputa pela posse e pelo usufruto da terra são os processos característicos de nossa história nacional primeira. Neste sentido, das muitas informações que o texto de frei Vicente veicula, a mobilização desse "povo novo" em torno da questão territorial é o tema que mais se aproxima de nossos objetivos, pois é o processo social de maior repercussão na formação da nação brasileira no período retratado pelo livro. Com efeito, das gerações nascidas da intensa miscigenação em solo americano surgirão os homens que, na luta pela salvaguarda do território, começaram a forjar a história da nação ao imprimir-lhe um sentido e um "estilo" próprios, exortando os sentimentos germinais da nacionalidade.

De antemão, pode-se dizer que a própria inspiração de frei Vicente, um brasileiro quinhentista, é a grande imagem desse sentimento de positividade em relação ao povo e à terra. Como, aliás, adverte Capistrano de Abreu, "para tentar a História habilitava-o o amor à terra natal [e] a certeza no seu futuro" ${ }^{24}$. No livro primeiro, que trata do descobrimento e da natureza da terra achada, há evidências abundantes dessa inspiração. Quando fala das condições naturais, por exemplo, o frade critica a idéia, que atribui a Aristóteles, de que a "zona tórrida" seria inóspita, argumentando que “a intensão de calor se modera com os ventos frescos do mar e umidade da terra, junto com a frescura do arvoredo de que toda está coberta; de tal sorte que os que a habitam vivem nela alegremente”. (Salvador, 1965 [1627]: 64) A isso junta uma visão de opulência natural e elabora uma noção de auto-suficiência do terri-

${ }^{19}$ Martins, Wilson, História da inteligência brasileira - Vol. I (1550-1794). São Paulo, Cultrix, 1977: 120

${ }^{20}$ Veríssimo, José, História da literatura brasileira: de Bento Teixeira (1601) a Machado de Assis (1908). Brasília, Editora da Universidade de Brasília, 1981: 57.

${ }^{21}$ Salvador, frei Vicente do, História do Brasil (1500-1627). São Paulo, Edições Melhoramentos, 1965 [1627]. As citações desta obra serão feitas no corpo do texto, entre parênteses, para evitar um número excessivo de notas de rodapé

${ }^{22}$ Bomfim, Manoel, O Brasil na América: caracterização da formação brasileira. Rio de Janeiro, Topbooks, 1997 [1929]: 7

${ }^{23}$ Iglésias, Francisco, Historiadores do Brasil: capítulos de historiografia brasileira. Rio de Janeiro, Nova Fronteira; Belo Horizonte, Editora da UFMG, 2000: 30.

${ }^{24}$ Abreu, Capistrano de, "Prolegômenos" in Salvador, op. cit.: 38. 
tório que o induz à própria idéia de soberania política quando, profeticamente, imagina a possibilidade de um império luso-brasileiro com sede no Brasil:

“(...) se alguma hora acontecesse (o que Deus não permita) ser Portugal entrado e possuído de inimigos estrangeiros, como há acontecido em outros reinos, de sorte que fosse forçado passar-se el-rei com seus portugueses a outra terra, a nenhuma o podia melhor fazer que esta. (...) pois a gente que cabe em menos de cem léguas de terra que tem todo o Portugal bem caberá em mais de mil que tem o Brasil, e seria este um grande reino (...)." (Salvador, 1965 [1627]: 162)

Contudo, essa visão favorável não impede que nosso autor demonstre um aguçado senso crítico, revelador de sua condição de "pensador social”. Já no segundo capítulo, frei Vicente é todo admoestações sobre a condição do país, em vista do mal uso de suas potencialidades, pois "os povoadores, por mais arraigados que na terra estejam e mais ricos que sejam, tudo pretendem levar a Portugal: papagaio real para Portugal" (Salvador, 1965 [1627]: 61). Por outro lado, se a citação pontua claramente para uma oposição entre o "nós" brasileiros da terra e o "eles" portugueses povoadores, isso não tolda a perspicácia sociológica do frade em identificar que as interpolações entre o público e o privado na conduta das pessoas - um dos traços marcantes do nosso ethos e até hoje um dos elementos definidores do "dilema brasileiro" 25 - era já um aspecto presente na mentalidade brasileira em Seiscentos:

"E isto não têm só os que de lá vieram, mas ainda os que cá nasceram, que uns e outros usam da terra, não como senhores, mas como usufrutuários, só para a desfrutarem e a deixarem destruída. Donde nasce também que nem um homem nesta terra é repúblico, nem zela ou trata do bem comum, senão cada um do bem particular (...) e tudo isto vem de não tratarem do que há cá de ficar, senão do que hão de levar pera o reino." (Salvador, 1965 [1627]: 58)

No que toca à formação do povo brasileiro, há uma evidente simpatia pela matriz étnica autóctone. Quando fala dos índios, frei Vicente demonstra visão positiva, ainda que singela: especula sobre sua procedência, tenta uma classificação e produz uma etnografia bastante relativizadora na qual trata, com inusitada isenção e objetividade, da guerra e dos rituais antropofágicos, entre outros temas. Contudo, a questão fundamental para a constituição do "povo novo", pelo menos durante o século XVI, é a história da relação entre o colonizador europeu e as populações indígenas. A miscigenação não é um tema de destaque, mas a gestação da nova raça fecundada pelo encontro interétnico é evocada através das histórias exemplares dos heróis e heroínas fundadores. O frade cita João Ramalho e a sua prole discorre sobre o conúbio de Jerônimo de Albuquerque com a índia Arcoverde, do qual nasceria o nosso primeiro herói nacional ${ }^{26}$, e destaca o idílio de Diogo Álvares Caramuru com a índia Paraguaçu. Com relação ao contato interétnico, muito mais é dito no decorrer de todo o livro e não pouco sobre o seu roteiro sangrento, mas dos primeiros tempos frei Vicente pinta um panorama de cordialidade, ainda possível num contexto em que o escambo estabelecia laços de reciprocidade valiosos:

“... aos portugueses que vão às suas aldeias, principalmente se lhes entendem a língua, [maldizem] no choro a pouca ventura de seus avós e os mais antepassados tiveram que não alcançaram gente tão valerosa como são os portugueses, que são senhores de todas as coisas boas que trazem à terra (...), como são machados, foices, anzóis, facas, tesouras, espelhos, pentes e roupas, porque antigamente roçavam os matos com cunhas de pedra e gastavam muitos dias em cortar uma árvore (...), e que desta maneira viviam mui trabalhados, porém agora fazem suas lavouras e todas as mais coisas com muito descanso, pelo que os devem de ter em muita estima." (Salvador, 1965 [1627]: 86/87)

Essa visão, contudo, é contrabalançada novamente por seu acurado senso crítico e objetividade historiográfica, dignos do nosso primeiro "pensador social". A reciprocidade dos tempos primitivos,

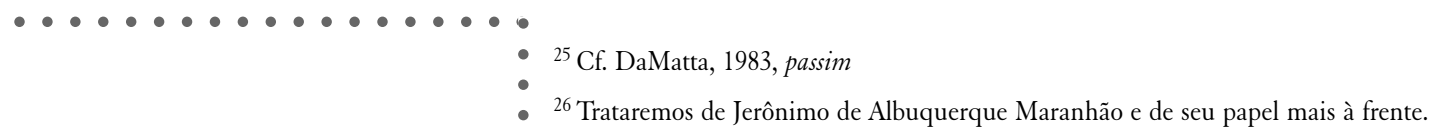


quando o estabelecimento português era ainda uma obra de aventureiros de passagem, torna-se uma relação crescentemente iníqua com a sistematização da empresa colonizadora, e a realidade do extermínio e da escravidão é avaliada com acuidade e reproche:

“(...) as guerras afugentavam os gentios (...), com o que os fez afastar do mar mais de sessenta léguas, seria melhor trazê-los por paz e por persuasão de mamalucos, que por lhes saberem a língua e pelo parentesco que com eles tinham (...), os trariam mais facilmente que per armas (...) os quais não iam tão confiados na eloqüência que não levassem muitos soldados brancos e índios confederados e amigos, com suas frechas e armas, com as quais, quando não queriam por paz e por vontade, os traziam por guerra ou por força. Mas ordinariamente bastava a língua do parente mamaluco, que lhes representava a fartura do peixe e mariscos do mar de que lá careciam, a liberdade de que haviam de gozar, a qual não teriam se os trouxessem por guerra. Com estes enganos e com algumas dádivas de roupas e ferramentas que davam aos principais e resgates que lhes davam pelos que tinham presos em cordas pera eles comerem, abalavam aldeias inteiras e em chegando à vista do mar, apartavam os filhos dos pais, os irmãos dos irmãos e ainda às vezes a mulher do marido, levando uns o capitão mamaluco, outros os soldados, outros os armadores, outros os que impetraram a licença, outros quem lha concedeu, e todos se serviam deles em suas fazendas e alguns os vendiam (...). Quebravam os pregadores os púlpitos sobre isto, mas era pregar em deserto." (Salvador, 1965 [1627]: 207)
É nesse panorama contraditório, no qual um território amplo e rico ambienta relações sociais que variam da reciprocidade à guerra de submissão e relações pessoais que produzem tanto a miscigenação quanto à escravidão, que surge o povo que fundaria a nação. Esse povo nascido da ambivalência, que ainda mais complexo se tornaria com a introdução dos africanos em fins do século XVI, começará a construir uma identidade coletiva a partir do momento em que sua mobilização for decisiva para a definição do perfil territorial do Brasil. Neste sentido, o relato seiscentista, ao descrever as condições da conquista do território, nos fornece indícios importantes para a questão que nos move: como se forja a nacionalidade a partir da luta do povo pela salvaguarda do território.

\section{A Guerra Brasílica}

A ocupação territorial do Brasil se inicia, como se sabe, a partir da expedição dos irmãos Pero Lopes e Martim Afonso de Sousa, em 1530. Até então, era muito mais rendoso para a Coroa portuguesa investir seu esforço no empreendimento asiático, usando os portos naturais da nova terra como escala no caminho das Índias, para a aguada das naves. Contudo, a terra prenhe do cobiçado pau de tinta atraía especuladores estrangeiros, principalmente franceses, que infestavam a costa, colocando em xeque a soberania lusitana sobre o território. Essa circunstância levou D. João III, em 1534, a instituir o regime das capitanias hereditárias.
O empreendimento das donatárias foi delegado a "homens de cabedal" - pequenos fidalgos, servidores do rei e militares que fizeram fortuna a partir de seu desempenho nas campanhas das Índias - que, aqui chegando, depararam-se com "terras imensas" já ocupadas pelos índios, ciosos de sua própria soberania. Assim, o cotidiano desses homens era tomado pelo embate com o "gentio", acostumado ao ambiente, muito maior em número, associado aos entrelopos franceses e cuja cultura tinha como valor fundamental a honra guerreira, para a qual a antropofagia era um dos rituais supremos. $\mathrm{O}$ resultado foi o insucesso quase completo da experiência.

Mesmo com a instituição do Governo-geral, em 1549, o cotidiano da ocupação territorial do Brasil continuava sendo marcado pela guerra, embora o processo de aliciamento dos indígenas pela catequese, pelo escambo e pelo convencimento militar fosse a cada dia mais bem sucedido. $\mathrm{O}$ que agravava a situação era a significativa presença de entrelopos franceses que, com suas feitorias, desestabilizava as posições lusitanas, principalmente pelas alianças que estabeleciam com os índios. Portanto, pode-se dizer que o século XVI brasileiro foi essencialmente bélico, mas se o estrangeiro era sempre considerado um inimigo, o íncola tinha que ser pensado - sobretudo por razões estratégicas - como um aliado potencial dos lusos.

É nessa correlação de forças que se ambientará a primeira manifestação coletiva de "união" entre os fundadores da nacionalidade, a ali- 
ança militar entre portugueses e índios, da qual resultará a guerra brasílica, o produto cultural mais original dos primeiros tempos do Brasil ${ }^{27}$. Quando a conquista do território se tornar dramática, em função de uma presença estrangeira mais efetiva, a estratégia da aliança com os índios será de importância fundamental. Isso fica claro nos episódios mais importantes da história territorial do Brasil até 1654: a campanha contra a França Antártica, a conquista da costa leste-oeste nordestina, a expulsão dos franceses do Maranhão e a dos holandeses da Bahia e de Pernambuco. $\mathrm{Na}$ guerra contra os franceses de Villegaignon a presença dos índios confederados aos portugueses terá uma importância fundamental. Mas aqui nos ateremos à análise da conquista das terras localizadas acima da capitania de Itamaracá e da expugnação da França Equinocial, dois eventos modelares nos quais a estratégia de aliança bem executada garantiu o êxito militar.

Desde meados da década de 1570, a situação da Paraíba se tornara uma questão preocupante para o Governo-geral, pois a presença dos franceses era intensa e os potiguaras, que com eles mantinham freqüente cooperação, se viam extremamente fortalecidos. Até então, havia um certo equilíbrio de forças na região porque os tabajaras, inimigos tradicionais dos potiguaras e aliados dos portugueses, conseguiam resistir em igualdade de condições ao assédio de seus opositores históricos. Essa situação não apenas colocava em perigo a soberania das terras compreendidas pela costa leste-oeste, como ameaçava a própria estabilidade das vizinhas capitanias de Itamaracá e Pernambuco, então as grandes provedoras da Fazenda Real.

A campanha da Paraíba se inicia em janeiro de 1584, com o sucesso da potente força luso-hispano-brasileira, que expulsa os franceses, afugenta os índios e estabelece um forte e uma povoação no sítio do Cabedelo. Contudo, já em junho, os potiguaras estarão fustigando o forte, e só em agosto de 1585 se tornará efetiva a ocupação da Paraíba, depois que Piragibe, um famoso chefe tabajara, se incorpora à falange luso-brasileira que defendia a posição. Frei Vicente atribui a ele o sucesso da campanha.

Conquistada a Paraíba, os esforços passaram a se dirigir para o Rio Grande do Norte, último bastião dos potiguaras e nova base francesa. É quando a estratégia das alianças se torna mais efetiva, levada pelas mãos do capitão Jerônimo de Albuquerque, o mameluco filho do "Adão pernambucano" com a índia Arcoverde. Depois da expulsão dos franceses, da retirada dos índios e do estabelecimento do forte dos Reis, o capitão liberta Ilha Grande, feiticeiro potiguara feito seu prisioneiro, e o manda convocar seus pares à paz, levando uma mensagem conciliató- ria aos grandes chefes Zorobabé e Ibiratinin. A missão teve pleno sucesso e a chamada "pacificação dos potiguaras" foi intensamente festejada pelo Governador-geral, que delegou comissão oficial para celebrá-la publicamente "com a solenidade do direito", diz frei Vicente, na cidade de Filipéia, em 11 de junho de 1599. A ela compareceram o governador da Paraíba, os oficiais da Câmara, o capitão-mor de Pernambuco e as nações Tabajara e Potiguara; frades franciscanos atuaram como intérpretes.

O sucesso de Jerônimo de Albuquerque na campanha da Paraíba e do Rio Grande o habilitou a se tornar o capitão-mor da maior de nossas campanhas militares antes da restauração pernambucana, a guerra contra os franceses estabelecidos no Maranhão. E, novamente, a sensibilidade militar do mameluco garantiu a posse do território ameaçado. Frei Vicente conta como o capitão arregimentou seu exército:

“(...) se foi logo às aldeias do nosso gentio pacífico e, por lhes saber falar bem a língua e o modo com que se levam, ajuntou quantos quis. (...) em uma aldeia (...) foi que pôs a uma parte um feixe de arcos e frechas, a outra outro de rocas e fusos, e mostrandolhos lhes disse: 'Sobrinhos, eu vou à guerra, estas são as armas dos homens esforçados e valentes, que me hão de seguir; estas as das mulheres fracas e que hão de ficar em casa fiando; agora

- 27 "A influência da cultura militar dos indígenas exerceu-se não no tocante ao equipamento militar mas à assimilação de suas táticas. Já no começo do século XVII, afirmava-se a noção de uma arte ou estilo militar próprio do Brasil e mais apropriado às suas condições que qualquer outro." (Cabral de Mello, Evaldo, Olinda restaurada: guerra e açúcar no Nordeste, 1630-1654. Rio de Janeiro,

Topbooks, 1998: 349). 
quero eu ver quem é homem ou mulher'. Não ajuntou com tanta facilidade o governador soldados brancos (...). Porém caiu em traça mui boa, que foi obrigar aos homens ricos e afazendados, que tinham mais de um filho, que dessem outro, com o que lhe sobejou gente...” (Salvador, 1965 [1627]: 403/4)

Foi com essa tropa que Jerônimo de Albuquerque expugnou os franceses de La Ravardière na Batalha de Guaxenduba, em 19 de novembro de 1614, usando as táticas da guerra brasílica - que Gilberto Freyre pensava ser "uma antecipação do estilo brasileiro de jogar futebol (...), um conjunto de qualidades de surpresa, de manha, de astúcia, de ligeireza e ao mesmo tempo de brilho e de espontaneidade individual... alguma coisa de dança e de capoeiragem" 28 . O "estilo brasileiro" também se evidenciaria na própria negociação da rendição dos franceses que, iniciada com agressividade pelas cartas enviadas pelo derrotado de seu retiro, foi se flexibilizando pela perícia e "manha" do negociador mameluco que, em sua última carta, admoestava La Ravardière com um argumento bem brasileiro e que expressa uma de nossas maiores potencialidades - a capacida- de de realizarmos muito dispondo de quase nada: "somos homens para quem um punhado de farinha e um pedaço de cobra (quando os há) é sustento sobejo, quem com isso se não acomodar, há de certo fugir à nossa companhia" 29 . No dia seguinte, os franceses capitularam.

A perspicácia de Jerônimo de Albuquerque numa negociação em que tinha, na verdade, pouca chance real de imprimir ao inimigo a derrota cabal pela força, obrigou o próprio governo da Metrópole, em documento oficial, a admitir "que sua política permite alcançar suavemente o mesmo que com as armas se pretende" 30 . Para Manoel Bomfim, isso evidencia que "de sob o estrategista e tático elegante, emerge o político, de uma política bem distinta, porque já é nitidamente brasileira" 31 .

Portanto, na questão geopolítica mais importante da primeira fase da história brasileira, temos um protagonista mameluco liderando um exército de voluntários brasileiros e de índios convocados por persuasão, que, através de táticas próprias da guerra brasílica, expulsou um bem armado e treinado contingente europeu, colocando um ponto final nas pretensões francesas sobre o território brasileiro. Pouco tempo depois, os holandeses invadiriam a Bahia, mas a resistência luso-brasileira valer-se-ia dos mesmos expedientes táticos para sitiar Salvador, não permitir a ocupação do recôncavo pelos batavos e preparar o terreno para a restauração da cidade pela esquadra mandada de Portugal e Espanha.

Embora devamos tributar à "armada dos vassalos” os preitos pela restauração da Bahia, havemos de admitir que, sem a ação das companhias volantes da infantaria brasílica que sitiaram Salvador por um ano e não permitiram a ocupação do recôncavo pelos holandeses, tudo poderia ter sido diferente no teatro da guerra baiana ${ }^{32}$. Quando mais não seja, a ação destra dos guerrilheiros desvelou a eficiência tática de um estilo próprio de lutar, o que nos leva a entrever, sem pejo, que o "povo novo" da nação começava a forjar a sua identidade e a conquistar a sua auto-confiança na luta pela defesa da terra em que germinava a nacionalidade, tal como ocorrera na guerra do Maranhão e tal como ocorrerá na guerra de Pernambuco. É o que reconhecemos num episódio corriqueiro da guerra, eternizado pela pena de frei Vicente do Salvador: o homem comum, agindo ardentemente, toma as cores do herói sob o olhar

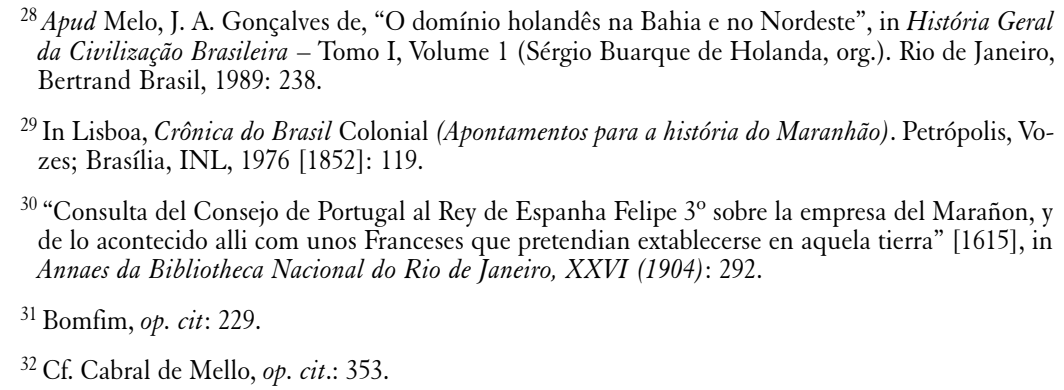


do cronista seu compatriota e esta transfiguração revela - pela ação do soldado e pelo testemunho do escritor - que já reverberava no espírito coletivo aquele sentimento solidário que liga espiritualmente o indivíduo ao seu povo fazendo de cada pessoa um bravo na defesa da sua coletividade. Aqui, outra vez evocamos o estro do frade historiador para render-lhe a nossa derradeira homenagem - que a sua História termina sob os fulgores da restauração da Bahia - e para sublimar o feito do infante baiano, um arquétipo do "povo novo" da nação e um símbolo vivo da brasilidade:

“(...) sobre este roçar de matos e derribar casas houve alguns encontros (...). E aqui testificou o capitão Lourenço de Brito do negro Bastião (...), que se adiantou a todos, dizendo que sua frecha não chegava tão longe como o pelouro dos arcabuzes, e assim lhe era necessário pera empregá-la nos inimigos chegar-se mais perto deles, o que também fez em outros encontros. E uma vez, já andando com eles à espada, dizendo-lhe os nossos negros que se retirasse, respondeu: 'Não retira, não, sipanta, sipanta', querendo nisto dizer que não era tempo de retirar quando brigavam já à espada, porque tinha experimentado dos holandeses que não eram tão destros nesta arma como nas de fogo, e assim vindo à espada tinha já o pleito por vencido." (Salvador, 1965 [1627]: 448)

\section{A cidadania à brasileira}

Mas, enquanto o povo estabelecia uma ligação emocional profunda com a terra, garantindo, com o seu sangue derramado, a integridade do alicerce da nação, as classes dirigentes arquitetavam uma estrutura institucional perversa, que condenaria este mesmo povo a ser um eterno refém dos interesses espúrios da elite. Como se sabe, durante o século XVI, a condição colonial já impunha sua herança ao perfil social brasileiro pela transposição das estruturas econômicas, políticas e jurídicas metropolitanas. É neste processo que se configura a base ética do nosso grande problema social, ainda hoje operante: a institucionalização da desigualdade.

Não é preciso ser um cientista social para saber que a desigualdade é um dos maiores problemas brasileiros - todos os indicadores econômicos e sociais contemporâneos expressam que a distribuição de renda no Brasil é uma das mais iníquas do mundo. Sabemos que esse problema tem uma profundidade histórica notável, já que foi inexoravelmente imposto pela economia colonial, mas não vamos discutir este processo, senão as bases institucionais que contribuíram para sua reprodução. Consideraremos principalmente o estatuto jurídico, já que ele é um dos elementos centrais de qualquer formação nacional.

Tal como alguns intérpretes da realidade social brasileira já destacaram, nossa sociedade tem um caráter extremamente pessoalizante, hierárquico ${ }^{33}$ e patrimonialista ${ }^{34}$, que se reflete na sua própria estrutura jurídica. Quer dizer, os indivíduos, formalmente iguais entre si, não são os agentes jurídicos operantes: na prática, são as pessoas, carregadas de atributos adquiridos pela sua posição econômica e pelo seu status, que travam relações com a Lei e com a Justiça. Com efeito, a instituição do sistema de capitanias hereditárias, já impunha esse traço, ao prever penas diferenciais a condenados de "qualidades diferentes", como fica dito na Carta de doação dada a Duarte Coelho, passada por D. João III em 5 de setembro de 1534 :

“(...) nos casos crimes hei por bem que o dito capitão e governador e seu ouvidor tenham jurisdição e alçada, de morte natural inclusive, em escravos e gentios e assim mesmo em peões cristãos homens livres em todos os casos assim para absolver como para condenar sem haver apelação nem agravo e nas pessoas de mor qualidade terem alçada de dez anos de degredo e até cem cruzados de pena sem apelação nem agravo." 35

A experiência das donatarias, como vimos, teve vida curta e resul-

${ }^{34}$ Cf. Faoro, Raymundo, Os Donos do Poder: Formação do patronato político brasileiro. São Paulo, Globo, 1991, passim.

35 "Carta donatária de Duarte Coelho", in Ribeiro, Darcy \& Moreira Neto, C. de Araújo, A fundação do Brasil: testemunhos (1500-1700). 2ª ed. Petrópolis, Vozes, 1993: 139. 
tados desastrosos, destacando-se os próprios desmandos praticados pelos capitães e seus prepostos na administração da Justiça. Aliás, essa foi uma das razões que levaram D. João III a decidir pela centralização do governo do Brasil em 1549, o que não impediu que o Regimento do primeiro ouvidor-geral, o responsável pelos negócios da Justiça no governo de Tomé de Sousa, mantivesse aquela forma discricionária:

“...[o ouvidor geral] teve alçada até morte natural, exclusive, nos escravos e peões cristãos livres; aos quais, quando competisse pena de morte, poderia esta aplicar-se sem apelação (...). Nas pessoas de mor qualidade teria o ouvidor alçada até cinco anos de degredo." 36

Portanto, a configuração da legislação penal no primeiro século da vida brasileira aponta para um sistema fundado na desigualdade ou, o que é pior, para um sistema legitimador da desigualdade. Essa estrutura se reproduzirá praticamente inalterada com a publicação das Ordenações Filipinas, o código que regeria as relações jurídicas entre 1580 e 1640 , que, no caso dos chamados “crimes contra a pessoa”, estabelecia uma dogmática em que os delitos eram julgados de acordo com "as distinções que ordenavam as desigualdades e os privilégios naquela sociedade" ${ }^{37}$.

Cumpre frisar que os crimes contra a pessoa colocam em jogo, precisamente, o conceito de integridade civil do indivíduo, pois são eles que, mais dramaticamente, deflagram as demandas ou disputas entre os sujeitos da ação, as quais mormente alimentam o chamado "campo jurídico" 38 , a arena da salvaguarda da cidadania. Neste sentido, a "maneira normal” como essas disputas são dirimidas reflete a própria dinâmica da vida civil de uma sociedade. Isso significa que, se a regra da desigualdade civil impera na solução das demandas inter-individuais, a Justiça opera a partir de um modelo de exclusão social que, no caso em tela, funciona a partir de uma hierarquia entre os cidadãos. $\mathrm{O}$ que torna essa operação mais abjeta é a brutal distorção da pirâmide social, em cuja base desproporcional está alocada a imensa maioria da população, enquanto o afilado cume é ocupado por uma reduzidíssima elite.

O elemento central e mais dramático dessa situação é que a pedagogia das penas nas Ordenações filipinas estava fundamentada, precipuamente, nos castigos corporais - inclusive a pena de morte - e na exprobação pública. Ora, a condição de nobreza, norte da ideologia social, definia, como o próprio texto do código coloca em diversas ocasiões, "pessoas de qualidade em que não cabem açoites”, cuja honra, base dessa condição, lhes dava a prerrogativa de não serem expostos à opinião pública ${ }^{39}$. Assim, em geral, a pena de açoite-e mesmo a de morte - dada aos plebeus e escravos era comutada por degredo quando se tratava de nobres e a exprobação no pelourinho com "baraço e pregão" era substituída pelo "pregão na audiência”, ou seja, no espaço restrito do tribunal.

Evidentemente, o que prevalecia nessa sistemática, além da maior suavidade das penas aplicadas aos nobres, era a cristalização da desigualdade civil num momento simbolicamente carregado de uma pedagogia, digamos, civilizadora, parafraseando Elias. Quer dizer, no momento em que o Estado vinha a público reafirmar as normas para o convívio entre cidadãos dele emanadas, Estado este que tinha como prática, tradição e costume afirmálas draconianamente, a mitigação das penas segundo a "qualidade" dos réus expressava, tão somente, o seu paradoxo mais essencial, a negação mesma de toda a idéia de cidadania: a diferença essencial dos homens perante a lei. Assim, definia-se um dos aspectos mais persistentes da $\mathrm{Ci}$ dadania à brasileira, a impunidade

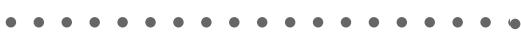

\footnotetext{
${ }^{36}$ Varnhagen, F. A., História geral do Brasil: antes de sua separação e independência de Portugal. Tomo I. Belo Horizonte, Itatiaia; São Paulo, EDUSP, 1981 [1854-1857]: 234.

${ }^{37}$ Lara, Silvia Hunold, "Introdução", Ordenações Filipinas, Livro V. São Paulo, Companhia das Letras, 1999: 46.

${ }^{38}$ Cf. Bourdieu, Pierre: "A força do Direito", in O poder simbólico. Lisboa, Difel; Rio de Janeiro, Bertrand Brasil, 1989

${ }^{39}$ Para detalhes, conferir o artigo 138, "Das pessoas que são escusas de haver pena vil" (Ordenações
} Filipinas, Livro V. São Paulo, Companhia das Letras, 1999 [1603]: 488). 
dos poderosos articulada à flagelação dos despossuídos, aquilo que Roberto DaMatta resumiu com o seu estilo direto: "Se o criminoso é pobre ou ignorante, pau nele! Mas se é um letrado, um doutor ou tem família, é tratado com todas as finezas a que uma pessoa tem direito." ${ }^{40}$. Hoje podemos observar que um dos signos mais expressivos desse aspecto perene, o estatuto da desigualdade civil entre a elite e o povo, é uma relíquia do código filipino, pois a chamada "prisão especial" tem a sua origem nas disposições das Ordenações acerca dos procedimentos processuais:

"Mandamos que os fidalgos de solar ou assentados em nossos livros, e os nossos desembargadores, e os doutores em leis ou em cânones, ou em medicina, feitos em estudo universal por exame, e os cavaleiros fidalgos ou confirmados por nós, e os cavaleiros das Ordens Militares de Cristo, Santiago e Aviz, e os escrivães de nossa Fazenda e Câmara, e mulheres dos sobreditos, enquanto com eles forem casadas ou estiverem viúvas honestas, não sejam presos em ferros, senão por feitos em que mereçam morrer morte natural ou civil. E pelos outros, em que não caibam as ditas penas de morte, serão presos sobre suas homenagens ${ }^{41}$, as quais devem fazer aos juízes que os prenderem, ou mandarem prender. E por eles lhes serão tomadas, e lhes darão por prisão o castelo da vila ou sua casa, ou a mesma cidade, vila ou lugar, segundo for a qualidade do caso.” ${ }^{42}$

Desse modo, mesmo com a evolução da dogmática jurídica - que desqualificou muitos crimes previstos no código quinhentista, que revogou os seus métodos de punir e que aboliu a diferenciação hierárquica das penas que ele estabelecia - as chamadas "regalias dos réus especiais”, que atualmente têm colocado em xeque a eqüidade da Justiça no Brasil, são uma herança das Ordenações filipinas. Isto apenas reforça o nosso pressuposto de que o estatuto da desigualdade civil, paradoxo essencial da cidadania no Brasil e fonte da torpe exclusão que caracteriza a nossa cena social em todos os tempos, é um traço marcante do processo de formação nacional e permanece, ainda que nos desvãos da arena judicial, a pautar o exercício da Justiça no Brasil.

\section{Um balanço idealista}

Dissemos no início deste ensaio que pretendíamos fazer um "balan- ço" da gênese do processo de formação nacional do Brasil para identificarmos alguns de seus principais pontos negativos e positivos, com o objetivo de contribuir para a superação de um dos grandes paradoxos da "mentalidade brasileira": a tensão entre autocrítica e auto-estima na reflexão sobre nós mesmos. Uma das expressões mais obtusas desse paradoxo é o lugar-comum de uma certa historiografia que nega a profundidade histórica da nacionalidade ${ }^{43}$, mas que vê na "herança colonial", mormente em sua estrutura escravocrata, a raiz de nossos principais problemas nacionais. Ao contrário dessa tendência sobretudo pessimista, nos colocamos aqui ao lado de outros estudiosos que, alinhando-se a um Gilberto Freyre ou a um Sérgio Buarque, pensam que a construção da nação é um processo social de longa duração e se perguntam: "quais as chances que tem este país de bem fazer face às más heranças da escravidão e a outras maléficas características da formação socioeconômica do Brasil?" ${ }_{4}$

Neste sentido, tencionamos estabelecer relações entre o passado colonial e o presente, de maneira a demonstrarmos que alguns traços marcantes do "espírito do povo" 
brasileiro têm uma permanência estrutural notável no curso do processo de formação nacional. Senão, vejamos. Nossa ambígua ideologia racial não seria uma modulação da ambivalência entre fusão e fricção interétnicas que governou a gênese do povo brasileiro, como bem demonstrou frei Vicente? Evidentemente que sim, pois havemos de concordar com o mestre de Apipucos que a sociedade brasileira, "nos começos e ainda hoje”, permanece "equilibrada sobre antagonismos" 45 . E a relação do indivíduo com o bem comum, veiculada na colônia pela "dicotomia da terra e do homem" 46 , - a qual levou frei Vicente a escrever, como vimos, que "nem um homem nesta terra é repúblico" - não estaria relacionada com a ação daquele político que trata o seu cargo como se fora propriedade particular ou com o homem comum que joga lixo na rua e "fura" a fila sem a menor cerimônia? Pensamos que sim, considerando, como Roberto DaMatta, que vivemos, brasileiros de todas as épocas, em uma "sociedade relacional”, na qual "o eixo da vida pública é englobado pelo eixo da casa" ${ }^{47}$.

Quanto à cidadania, não há o que acrescentar ao que já dissemos, pois as analogias entre o passado e o presente são gritantes. Mas, ainda no campo da ética, o que dizer do "espírito de conciliação" de Jerônimo de Albuquerque, a forma tipicamente brasileira de acomodação de conflitos que tem origem antiga e curso perene no comportamento político brasileiro de todas as épocas ${ }^{48}$ ? Ora, o capitão mameluco era um "homem cordial" e, como sentenciou Sérgio Buarque, "a contribuição brasileira para a civilização será de cordialidade" 49 .

Portanto, não temos nenhum pejo em afirmar que as raízes da nacionalidade eclodiram nas primícias do Brasil colonial, mas temos ainda um ponto a tratar. Em face de nossas ambigüidades, paradoxos e problemas evidenciados no curso da formação nacional, quais são as nossas perspectivas para o futuro? Diremos, apenas, que o nosso destino como nação depende, tão somente, da força do povo. $\mathrm{O}$ mesmo povo mestiço que empregou o seu vigor na defesa do território, colocando em prática os preceitos da guerra brasílica, a qual evidencia, emblematicamente, três características positivas fundamentais do espírito brasileiro: a criatividade, a conjunção e a capacidade de realização. Afinal, somos um povo que "tira leite de pedra" mas "não teme a própria morte", que "vive na corda bamba" mas que tem "jogo de cintura", que é "pobre, pobre, pobre" mas que "faz da carência virtude".

Finalmente, nos resta apresentar o resultado do nosso "balanço" sociológico, o que faremos de uma maneira alegórica e idealista, com o intuito de provocar o debate. Coloquemos lado a lado o destemido infante Bastião, o capitão mameluco Jerônimo de Albuquerque Maranhão, e o legislador sacripanta das Ordenações filipinas e teremos os termos da dialética nacional brasileira sob o fiel da consciência histórica: somos uns bravos com jogo de cintura, uns conciliadores marotos, uns elitistas autoritários. Talvez possamos construir uma nação maior se aliarmos, como é do nosso espírito, valentia com malícia e, cordialmente, dermos um passa-fora na elite.

- ${ }^{45}$ Freyre, Gilberto, Casa Grande \& Senzala: formação da família brasileira sob o regime da economia patriarcal. $29^{\mathrm{a}}$ ed. Rio de Janeiro, Record, 1994 [1933]: 8.

${ }^{46}$ Cabral de Mello, Evaldo, "Uma Nova Lusitânia", in Viagem incompleta. A experiência brasileira (1500-2000). Formação: histórias (Carlos Guilherme Mota, org.). São Paulo, Editora Senac, 2000: 93.

${ }^{47}$ DaMatta, 1987: 18 e 26.

${ }^{48}$ Cf. Rodrigues, José Honório, Conciliação e Reforma no Brasil: Um desafio histórico-cultural. Rio de Janeiro, Nova Fronteira, 1982 [1964]: 29.

${ }^{49}$ Holanda, Sérgio Buarque de, Raízes do Brasil. Rio de Janeiro, José Olympio, 1988 [1936]: 106. 